\title{
Bireylerin Sağlıklı Yaşam Konusuna İlişkin Görüşleri
}

\author{
DOI: 10.26466/opus.918671
}

\author{
* \\ Nuriye Değirmen* - Filiz Özyiğit ** \\ * Dr. Öğr. Üyesi, Kütahya Sağlık Bilimleri Üniversitesi, Kütahya/Türkiye \\ E-Posta: nuriye.degirmen@ksbu.edu.tr ORCID: $\quad$ 0000-0002-7278-978X \\ ** Doç. Dr., Bandırma Onyedi Eylül Üniversitesi, Tıp Fakültesi, Bandırma /Türkiye \\ E-Posta: filiz.ozyigit@yahoo.com ORCID: $\quad$ 0000-0002-0062-4281
}

\section{Öz}

$B u$ çalışmada bireylerin sağlık davranışları ve görüşlerinin belirlenmesi amaçlanmıştır. Tanımlayıcı çalışmaya bir aile să̆lık merkezinde tedavi gören 330 birey katıldı. Çalışma 2019 Ekim-Aralık tarihleri arasında yapıldı. Bilgilendirilmiş gönüllülerle ve etik kurul izniyle yürütüldü. Literatüre dayalı hazırlanan anketler yüz-yüze uygulandı. Katılımcıların \%71,7'si kadın, yaklaşık yarısı evli ve üniversite mezunu, yaklaşık üçte biri ev hanımı, \%81'i çekirdek aile, \%71,8'inin ekonomik durumu orta, \%88,9'unun sosyal güvencesi vardır, \%67,7'si kent kültüründe, \%20,1'i sigara alkol kullanmaktadır, \%65,8'i organik besin tüketmekte, \%57,1'i GDO'lu ürünleri kullanmakta, \%62,8'i egzersiz yapmamakta, \%61,1'inin okuma alışkanlığı vardır. Bekarlarda sağlıkta dinlenmenin önemli olduğu düşüncesi yaygındı ( $p<0.05)$. Üniversite mezunlarmın \%98'inde olumlu düşüncenin hastalıklarla mücadelede önemli olduğu düşüncesi yaygındı ( $p<0.05)$. Memurların, işçilerin, emeklilerin çoğunda olumlu düşüncenin hastalıklarla mücadelede önemli olduğu görüşü bulunmaktaydı $(p<0.05)$. Stresli yaşamın hastalıklara etkisiyle aileyle yaşama arasında ilişki bulunmuştur $(p<0,05)$. GDO'lu ürün kullanmayanlarda olumlu düşüncenin hastalıklara etkisi düşüncesi yaygındı $(p<0,05)$. Egzersiz yapmayanlarda; dinlenmenin sağllğa etkisi, olumlu düşüncenin ve stresli yaşamın hastalıklara etkisi düşünceleri yaygındı $(p<0,05)$. Okuma alı̧̧kanlığı olanların; inancın ve dinlenmenin sağllğa etkisi düşünceleri yaygındı $(p<0,05)$. Kent kültüründekilerde stresli yaşamın hastalı̆̆a etkisi düşüncesi yaygındı $(p<0,05)$. Çoğunluğu reçeteli ilaç kullanımını önemsemekte, geleneksel yöntemlere olumsuz bakmaktaydı. Sonuç: Sağllkta olumlu düşünme, egzersiz, stresten korunma, inancon önemsendiğ i ve sosyo-demografik değişkenlerle olumlu düşünce, dinlenme, GDO lu, organik besin tüketimi, stresli yaşam arasında ilişki belirlendi.

Anahtar Kelimeler: Sağlıklı Yaşam, Egzersiz, Stres. 


\title{
Individuals Opinion on Healty Living Subject
}

$*$

\begin{abstract}
Aim of this study is evaluation of health behaviours and opinions of individuals. Descriptive, 330 individuals in a Family Health Center, made between October-December 2019 of voluntary by face to face. $71.7 \%$ of the participants are woman, half are married and university graduates, $81 \%$ of them live in a elementary family, $71.8 \%$ of them have a mid economic situation, $88.9 \%$ of them have a social security, $67.7 \%$ feel themselves in urban culture, $20.1 \%$ smoke and use alcohol, $65.8 \%$ of them stated that they consume organic food, $57.1 \%$ of them use GMO products, $62.8 \%$ of the don't exercise, It is common for single individuals to think that resting is important for being healty $(p<0.05)$. The thoughts were common on people who don't exercise; effect on rest on health, the effect on positive thinking on diseases and the effect on stressful life on diseases $(p<0,05)$. People who have a reading habit; thoughts were common on, the effect of belief and rest on health $(p<0,05)$. Most of them care about the using prescription drugs. Result: It found important that positive thinking, exercising, avoiding stress in being healty by participants, relationship between socio-demographic variables and positive thinking, resting GMO, organic food consumption and stressful life.
\end{abstract}

Key Words: Healty Lifestyle, Exercise, Stress. 


\section{Giriş}

Sağlıklı olma, bireylerin fiziksel, ruhsal ve sosyal açıdan iyi olmaları şeklinde tanımlanır. Geçmişte fiziksel iyilik halini ifade etmek için kullanılan sağlık kavramı, günümüzde bireyin ruhsal ve maddi yönler de dahil diğer yönleriyle iyi olma halini ifade eden geniş kapsamlı bir kavramdır (Şimşekoğlu ve Mayda, 2016, s.19).

Hem hastalık durumunda hem de sağlıklı iken bireylerin sağlık durumlarını nasıl koruyacakları ve iyileştirecekleri konusunda yapılması gerekenler ortada olmasına karşın bazı yanlış bilgi ve inançlar bu konudaki davranışlara etki etmektedir. Bireylerin sağlıklı olma ve hastalık hali ile ilgili düşünce ve davranışlarını ifade eden sağlık inancı, sağlık için neler yapılması gerektiği hususundaki davranışlara yön vermesi bakımından önem taşımaktadır (Ünsal, 2017, s.11).

Günümüzde, egzersiz, diyet, sigara içme ve stres gibi yaşam biçimi unsurlarının sağlığı ve kardiyo-vasküler hastalık riskini etkilediği, kalp hastalığı, hipertansiyon ve diyabet gibi kronik hastalıklardaki morbidite ve mortalitenin yaşam biçimi değiş̧iklikleri ile önemli ölçüde azaltılabildiği bilinmektedir (Ferguson, 1998, s.811).

Beslenme; büyümek, vücut fonksiyonlarını yapabilmek ve yaşamı sağlıklı, mutlu olarak sürdürebilmek amaciyla vücudun yediğimiz gidalardan yararlanmasidır (Kavas, 2003,s.6)

Toplumun ve bireylerin sağlıklı ve güçlü olarak yaşamasında, ekonomik ve sosyal yönden gelişmesinde, refah düzeyinin artmasında yeterli ve dengeli beslenme temel şartlardandır (Soylu, 2006).

Stres, Latince kökenli ve İngiliz dilinde kullanılan bir terimdir. İsim olarak birinci anlamı "zorlanma, gerilme ve baskıdır". Farklı zamanlarda farklı anlamlarda kullanılsa da 18. ve 19. yüzyıllarda bu kavram "güç, baskı, zor" gibi anlamlar ile objelere ve insanlara yönelik kullanılmıştır. Bir diğer anlamda ise stres, organizmanın dengesini bozabilecek etkenlerin tümüdür. Medikal açıdan stres insanların dış ve iç dünyaları tarafından tehdit edilip, kafa tutma durumları ile karşı karşıya kaldıkları durumlar karşısında ürettikleri psikolojik, fizyolojik ve davranış reaksiyonları olarak ifade edilebilir. Stres iyi ya da kötü olabilir. Stresin insana ihtiyacı olan gücü ve uyanıklığı verdiği durumlar iyi, iyi yönlendirilmediği ve insan için zararlı olduğu ve hastalıklara sebep 
olduğu durumlar ise kötüdür. Çoğu zamanda halk arasında stres teriminin karşılığı kötüdür (Aydın ve Örnek, 2008). Stres durumunun uzaması sonucu organ, sistem ve fonksiyonlarda bozulma meydana gelir (Balcıŏlu,2005).

İnsanların olumlu sağlık inançlarına sahip olması, sağlık konusundaki davranışlarını da etkilemekte ve onları sağlıklarını koruyucu önlemleri alma konusunda harekete geçirmektedir (Şimşekoğlu ve Mayda, 2016, s.19). İnancın sürekli bir olgu olması (Peker ve Zengin, 2019, s.45) sağlık konusunda oluşacak olumlu düşünce ve inançların kalıcı bir şekilde yön vermesini sağlamaktadır (Ertüzün ve Karaküçük, 2014, s.1). Bu nedenle sağlı̆̆1 korumaya ve geliştirmeye yönelik yapılması gerekenler konusundaki inançlar, bireylerin hem tedavi sürecinde yapılması gerekenler hem günlük yaşamda sağlı̆̆ı korumaya ve geliştirmeye yönelik tutum ve davranışlarını etkilemektedir.

Dinlenme kişilere güç, motivasyon, mental ve fiziksel sağlık, yaşam kalitesinde artış sağlar. Yorulma organ ve organ sistemlerindeki performans veya fonksiyonların azalmasıdır. Yorulma yeterli bir dinlenme ile dengelenir. Yorulmaya bağlı olarak organizmada; dikkatin azalması, algılama kaybı ve yavaşlama, düşünme zorluğu, verimli olma isteğinde azalma, zihinsel ve bedensel çalışmada verim kayıpları görülür. Dinlenme belli bir aktivitenin kisttlı olarak kesilmesi, kişinin kendini rahatlatma girişimi olarak tanımlanabilir. Dinlenme sürekli hareketsizliği ifade etmez (aktif dinlenme). Hastalık durumunda yeterli dinlenme çok önemlidir. Bireyin hastaneye yatırılması birtakım engelleri ortaya çıarır. Hastalığından dolayı kaygılı olan birey bilinmeyen bir çevreye, yeni yüzlere, alışık olmadığı gürültülere ve genellikle ağrılı ya da rahatsız edici olan tanı ve tedavi işlemleri ile karşı karşıyadır. Hastaya dinlendirici bir ortam sağlamak hemşirenin en önemli işlevidir (Çakırcalı,1998).

Yaşam biçimi sağlığg önemli ölçüde etkilemekte ve sağlıklı yaşam biçimi değişiklikleriyle morbidite ve mortalitede önemli azalmalar sağlanabileceği bilinmektedir. Konuyla ilgili araştırmalara gereksinim vardır. Bu çalışmada bireylerin sağlık davranışları ve görüşlerinin belirlenmesi amaçlanmıştır. 


\section{Yöntem}

\section{Örneklem}

Tanımlayıcı tipte planlanan çalışmanın örneklemini Kütahya ili merkezinde yer alan bir aile sağlık merkezinde (ASM) tedavi gören 330 hasta ve yakını oluşturmaktadır. Bu ASM nin seçilmesinin nedeni; ASM'nin bulunduğu Kütahya merkezde yer alan Gaybi efendi mahallesi Kütahya gelenek ve kültürünü yansıtmaktadır, araştırma konumuzda sağlık inançlarına odaklandığımız için geniş bölgede yaşayan 10.097 nüfüslu tarihi semt ele alınmış, doktor seçme prensibine göre çalışıldığ 1 için çevredeki servi mahallesi, meydan mahallesi, ahmedoğlu köyü, çobanlar köyü gibi geniş yelpazede veri çeşitliliği örnekleme yöntemi sağlamak için farklı kişilere ulaşılmaya çalışılmıştır. Araştırma evreni şu şekilde hesaplanmıştır; evrenin 100.000.000 olduğu durumda a= 0,05 anlamlılık düzeyinde ve $\mathrm{d}=0.05$ örnekleme hatası $\mathrm{p}=0,5 \mathrm{q}=0,5$ için 385 kişi yeterli görülmüştür. Çalışma anket uygulaması 2019 Ekim-Aralık tarihleri arasında yapılmıştır. Örneklemi bu aylar arasında ilgili ASM den hizmet alan hasta ve yakınları gönüllü katılımcılar oluşturmuştur.

\section{Etik Boyut}

Çalışma katılımcılara bilgilendirilmiş gönüllü olur formu imzalatılarak ve etik kurul izni; Kütahya Sağlık Bilimleri Üniversitesinden 18.12.2018 tarih 4135 sayılı yazı ile alınarak yürütülmüştür. Çalışmaya katılan gönüllülere, araştırmacılar tarafından literatüre dayalı hazırlanan anket formları yüz yüze anket yöntemi ile uygulanmıştır. Çalışmada Helsinki Bildirgesi ilkelerine uyulmuştur.

\section{Bağımlı Değişkenler}

Katılımcıların sosyo demografik verileridir.

\section{Bağımsız Değişkenler}

Katılımcıların sağlıklı yaşam sorularına verdikleri cevaplarıdır. 


\section{Veri Toplama Araçları}

Çalışmanın verileri anket yöntemi ile elde edilmiştir. Çalışmanın verilerini elde etmek için araştırmacılar tarafından literatüre dayalı hazırlanan anket formu 2 bölümden oluşmaktadır ( Ellison ve Levin, 2018, s.449. Kurt, Pekünlü, Çatıkkaş ve Atalağ, 2010, s.70). Anketin ilk bölümünde bireylerin demografik özelliklerini, aile yaşamlarını, sağlık durumlarını, beslenme şekillerini, ekonomik koşullarını belirlemeye yönelik sorular yer almaktadır. İkinci bölümde ise bireylerin sağlıklı olma hakkındaki görüşlerini belirlemeye yönelik sorular yer almıştır.

\section{Analiz Yöntemleri}

Bireylerin sosyo-demografik özellikleri, sağlıklı olma ile ilgili düşüncelerini belirlemek için tanımlayıcı istatistiklere başvurulmuştur (Büyüköztürk, 2018, s.1).

Katılımcıların sosyo-demografik özellikleri ile sağlıklı hakkında düşünceler arasında anlamlı ilişkilerin tespiti için ki-kare analizine başvurulmuştur.

\section{Sinirlılıklar}

Çalışma bulguları bir ASM den ilgili tarihte hizmet alan katılımcıların düşünceleri ile sınırlıdır.

\section{Bulgular}

\section{Demografik bulgular}

Tablo 1'de 330 hasta ve hasta yakının oluşturduğu örneklem içerisinde çoğunluğu kadınlardır, yaklaşık \%48'i evli bireylerdir, \%47,3'ü eğitim düzeyi yüksektir. Çoğunlukla öğrenci ve ev hanımlarıdır. Orta düzeyde ekonomik duruma sahip bireyler \%71,8'ini oluşturmaktadır. Genellikle çekirdek ailede yaşamaktadırlar ve ortalama olarak 2 çocuğa sahip 4 kişinin aynı evde yaşadığı haneler bulunmaktadır. Ortalama yaş düzeyi 
$34^{\prime}$ tür. \%88,9'unun sağlık güvencesinin vardır. Katılımcıların yaklaşık \%80'i sigara alkol kullanmamaktadır. Yaklaşık 3'te 2'si organik beslenmemekte, yaklaşık dörtte biri ise GDO'lu ürünleri kullanmamaktadır. Çoğunluğu spor yapmamaktadır. Kendini kent kültüründe hissedenler oldukça fazladır. Okuma alışkanlığının da yüksek olduğu görülmektedir.

\section{Tablo 1. Demografik Bulgular}

\begin{tabular}{|c|c|c|c|}
\hline & & Siklık & Yüzdelik \\
\hline \multirow[t]{2}{*}{ Cinsiyet } & Kiz & 236 & $71,7 \%$ \\
\hline & Erkek & 93 & $28,3 \%$ \\
\hline \multirow[t]{3}{*}{ Medeni Durum } & Evli & 146 & $44,5 \%$ \\
\hline & Bekar & 171 & $52,1 \%$ \\
\hline & Dul & 11 & $3,4 \%$ \\
\hline \multirow[t]{3}{*}{ Eğitim Durumu } & İlkokul & 87 & $27,3 \%$ \\
\hline & Lise & 81 & $25,4 \%$ \\
\hline & Üniversite & 151 & $47,3 \%$ \\
\hline \multirow[t]{5}{*}{ Meslek } & Memur & 48 & $16,2 \%$ \\
\hline & İşçi & 56 & $18,9 \%$ \\
\hline & Emekli & 22 & $7,4 \%$ \\
\hline & Ev hanımı & 77 & $26,0 \%$ \\
\hline & Öğrenci & 93 & $31,4 \%$ \\
\hline \multirow[t]{3}{*}{ Aile ile yaşama } & Evet & 242 & $74,7 \%$ \\
\hline & Hayır & 79 & $24,4 \%$ \\
\hline & Bilmiyorum & 3 &, $9 \%$ \\
\hline \multirow[t]{2}{*}{ Sigara alkol kullanımı } & Var & 65 & $20,1 \%$ \\
\hline & Yok & 259 & $79,9 \%$ \\
\hline \multicolumn{2}{|c|}{ Beslenme ile ilgili olarak organik besin tercihEvet } & 214 & $65,8 \%$ \\
\hline \multirow[t]{2}{*}{ ediyor musunuz? } & Hayır & 66 & $20,3 \%$ \\
\hline & Bilmiyorum & 45 & $13,8 \%$ \\
\hline \multicolumn{2}{|c|}{ Besinlerde GDO' lu ürünleri kullanmamayaEvet } & 185 & $57,1 \%$ \\
\hline \multirow[t]{2}{*}{ dikkat ediyor musunuz? } & Hayır & 92 & $28,4 \%$ \\
\hline & Bilmiyorum & 47 & $14,5 \%$ \\
\hline \multirow[t]{3}{*}{ Egzersiz yapıyor musunuz? } & Evet & 102 & $31,4 \%$ \\
\hline & Hayır & 204 & $62,8 \%$ \\
\hline & Bilmiyorum & 19 & $5,8 \%$ \\
\hline \multirow{3}{*}{$\begin{array}{l}\text { Kitap/Gazete/dergi okuma ile ilgili } \\
\text { alı̧̧kanlıklarınız var mı? }\end{array}$} & Evet & 198 & $61,1 \%$ \\
\hline & Hayır & 116 & $35,8 \%$ \\
\hline & Bilmiyorum & 10 & $3,1 \%$ \\
\hline \multirow[t]{3}{*}{ Ekonomik durum } & Düşük & 35 & $10,7 \%$ \\
\hline & Orta & 234 & $71,8 \%$ \\
\hline & İyi & 57 & $17,5 \%$ \\
\hline \multirow[t]{2}{*}{ Sosyal güvence } & Var & 289 & $88,9 \%$ \\
\hline & Yok & 36 & $11,1 \%$ \\
\hline \multirow[t]{2}{*}{ Kendinizi hangi kültürde hissediyorsunuz? } & Köy kültürü & 102 & $32,3 \%$ \\
\hline & Kent kültürü & 214 & $67,7 \%$ \\
\hline \multirow[t]{3}{*}{ Aile yapıs1 } & Geniş aile & 48 & $14,7 \%$ \\
\hline & Çekirdek aile & 265 & $81,0 \%$ \\
\hline & Parçalanmış aile & 14 & $4,3 \%$ \\
\hline
\end{tabular}

Tablo 2'de katılımcıların çoğunluğunca inancın sağlıkla mücadelede önemli olduğu, dinlenmenin sağlıklı olmada önemli olduğu, olumlu 
düşüncelerin hastalıklar üzerinde etkisinin olabileceği düşüncesi hakimdir.

Tablo 2. Să̆lıklı olma düşüncesi ile ilgili bulgular

\begin{tabular}{|c|c|c|c|}
\hline \multirow{2}{*}{ İnanç hastalıkla mücadelede önemlidir. } & & Siklık & Yüzdelik \\
\hline & Evet & 268 & $83,5 \%$ \\
\hline & Hayır & 25 & $7,8 \%$ \\
\hline & Bilmiyorum & 28 & $8,7 \%$ \\
\hline \multirow{3}{*}{$\begin{array}{l}\text { Dinlenme sağlıklı } \\
\text { koşullardandır. }\end{array}$} & liEvet & 304 & $94,7 \%$ \\
\hline & Hayır & 8 & $2,5 \%$ \\
\hline & Bilmiyorum & 9 & $2,8 \%$ \\
\hline \multicolumn{2}{|c|}{ Olumlu düşünce hastalıklarla savaşta bedeneEvet } & 307 & $95,6 \%$ \\
\hline \multirow[t]{2}{*}{ yardım eder. } & Hayır & 5 & $1,6 \%$ \\
\hline & Bilmiyorum & 9 & $2,8 \%$ \\
\hline \multicolumn{2}{|c|}{ Stresli yaşam koşulları olan insanlar daha sıkEvet } & 307 & $95,6 \%$ \\
\hline \multicolumn{2}{|c|}{ hasta olurlar ve hastalıkları daha uzun sürer. Hayır } & 4 & $1,2 \%$ \\
\hline & Bilmiyorum & 10 & $3,1 \%$ \\
\hline
\end{tabular}

Tablo 3'de bireylerin inançlarının, yaşam koşullarının ve düşünce sistemlerinin çeşitli özelliklerine göre dağılımı incelenmiştir. 
Tablo 3. Sağlıklı olma düşüncesi ve sosyo demografik veriler

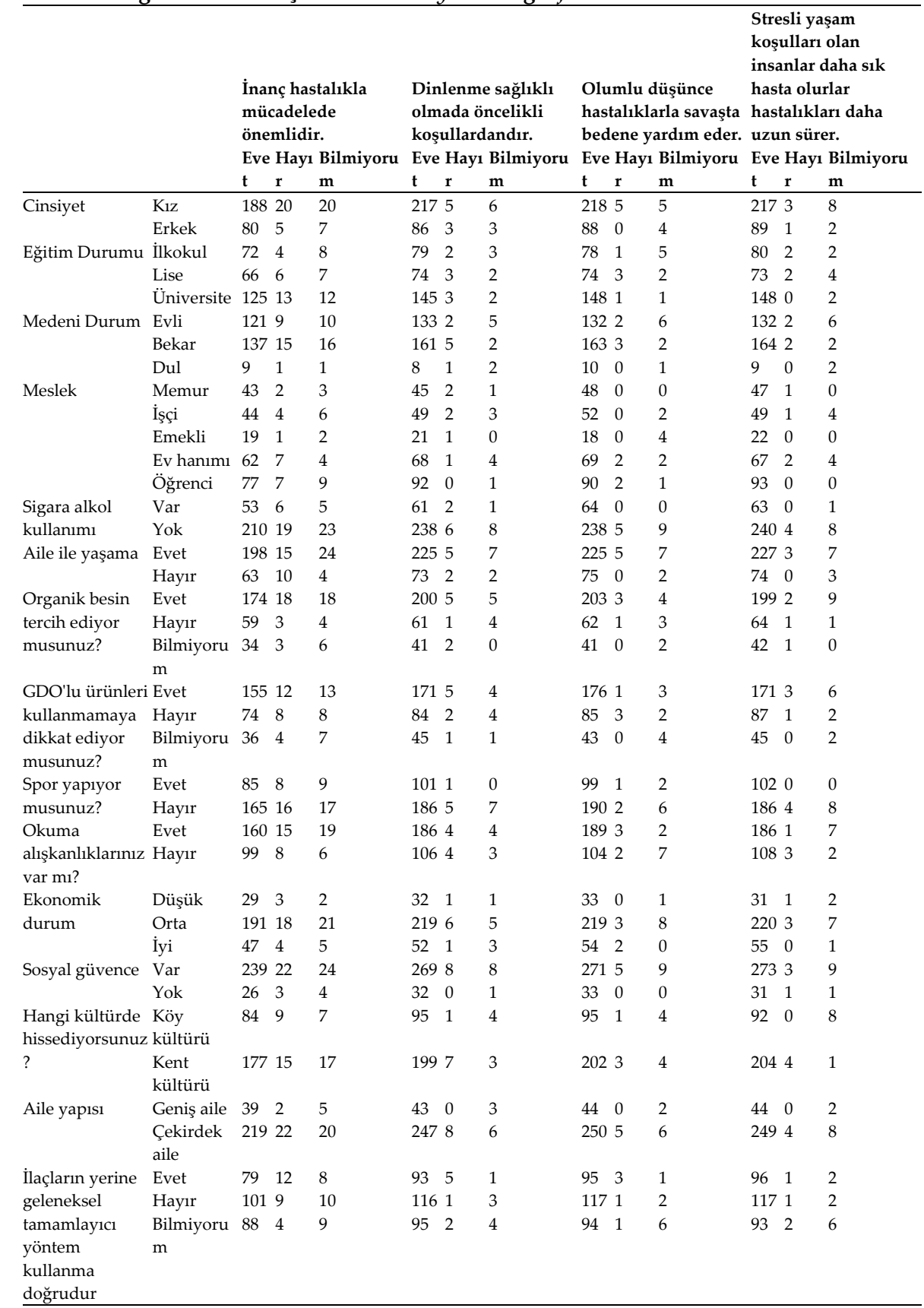


Tablo 4'de bireylerin sağlıklı olma hakkındaki düşünceleri ile sosyodemografik özellikleri arasında ilişkinin incelenmesi amacıyla ki-kare testine başvurulmuştur. Pearson ki-kare katsayısının kullanılabilmesi için bazı varsayımların sağlanmış olması gerekmektedir. Ancak örneklemimizin bazı gözlemlerinde yeterli gözlem sayısına ulaşılamaması nedeniyle exact sig (2 yön) değerine başvurulmuştur.

Tablo 4. Sağlıklı olma düşüncesi ile demografik verilerin karşılaştırılması

\begin{tabular}{|c|c|c|c|c|}
\hline & $\begin{array}{l}\text { İnanç hastalıkla } \\
\text { mücadelede } \\
\text { önemlidir. } \\
\text { P değerleri }\end{array}$ & $\begin{array}{l}\text { Dinlenme sağlıklı } \\
\text { olmada öncelikli } \\
\text { koşullardandır. } \\
\text { P değerleri } \\
\end{array}$ & $\begin{array}{l}\text { Olumlu düsüunce } \\
\text { hastalıklarla } \\
\text { savaşta bedene } \\
\text { yardım eder. } \\
\text { P değerleri }\end{array}$ & $\begin{array}{l}\text { Stresli yaşam } \\
\text { koşulları olan } \\
\text { insanlar daha sık } \\
\text { hasta olurlar ve } \\
\text { hastalıkları daha } \\
\text { uzun sürer. } \\
\text { P değerleri }\end{array}$ \\
\hline Cinsiyet & 549 & 833 & 248 & 887 \\
\hline Medeni Durum & 881 &, $017^{*}$ & ,332 &, $033^{*}$ \\
\hline Eğitim Durumu & ,858 & 767 &, $040^{*}$ & 140 \\
\hline Meslek & ,918 & 312 &, $006^{*}$ & 080 \\
\hline Aile ile yaşama & 207 & 108 &, 556 &, $028^{*}$ \\
\hline Sigara alkol kullanımı & 853 & 805 & 151 &, 550 \\
\hline $\begin{array}{l}\text { Organik besin tercih ediyor } \\
\text { musunuz? }\end{array}$ & ,504 & 284 & 685, & 468 \\
\hline $\begin{array}{l}\text { GDO'lu ürün kullanmamaya } \\
\text { dikkat ediyor musunuz? }\end{array}$ & ,500 & 898 & 031 & 896 \\
\hline Spor yapiyor musunuz? & 1,000 & $019^{*}$ &, $045^{*}$ &, $050^{*}$ \\
\hline $\begin{array}{l}\text { Kitap/Gazete/dergi okuma } \\
\text { alışkanlıklarınız var mı? }\end{array}$ &, $036^{*}$ &, $048^{*}$ & 114 & ,254 \\
\hline Ekonomik durum & ,982 & ,809 & ,366 & ,583 \\
\hline Sosyal güvence & ,752 & 846 &, 513 & ,747 \\
\hline $\begin{array}{l}\text { Kendinizi hangi kültürde } \\
\text { hissediyorsunuz? }\end{array}$ & 817 & ,227 & 616, &, $000^{*}$ \\
\hline Aile yapısı & 289 & ,226 &, 540 & ,836 \\
\hline $\begin{array}{l}\text { Hastallğınız için kullanılan } \\
\text { ilaçların yerine geleneksel ve } \\
\text { tamamlayıcı tıp yöntemi } \\
\text { kullanmak doğrudur? }\end{array}$ & ,325 & 214 & 107 & ,346 \\
\hline
\end{tabular}

Not: ki kare analizi ile istatistiki açıdan $p$ değeri anlamlı değerler bold gösterilmiştir.

Tablo 3 ve 4'de medeni durum ile "dinlenme sağlıklı olmada öncelikli koşullardandır." ve "stresli yaşam koşulları olan insanlar daha sık hasta olurlar ve hastalıkları daha uzun sürer." ifadeleri arasında istatistiki açıdan anlamlı ilişki tespit edilmiştir $(\mathrm{p}<0,05)$.

Bekar bireyler arasında dinlenmenin sağlıklı olmada öncelikli koşullar arasında olduğu düşüncesinin daha yaygın olduğu tespit edilmiştir. 
Eğitim düzeyi ile olumlu düşüncenin hastalıklarla savaşta bedene yardım edebileceği düşüncesi arasında da anlamlı ilişki tespit edilmiştir $(p<0,05)$. Üniversite mezunları arasında \%98 oranında olumlu düşüncenin hastalıklarla mücadelede önemli olduğu belirtilmiştir.

Olumlu düşüncenin hastalıklarla mücadelede önemli olduğu düşüncesi ile meslek arasında da anlamlı bir ilişki tespit edilmiştir $(p<0,05)$. Memurların, işçilerin, emeklilerin hepsi olumlu düşüncenin hastalıklarla mücadelede bedene yardım edeceği görüşünde hem fikirdir.

Stresli yaşam koşullarının hastalıklar üzerindeki etkisi ile aile yaşama arasında istatistiki açıdan anlamlı ilişki tespit edilmiştir $(\mathrm{p}<0,05)$.

GDO'lu ürün kullanmayanlarda daha fazla oranda olumlu düşüncenin hastalıklarla savaşta etkili olacağı düşüncesi yaygındır $(\mathrm{p}<0,05)$.

Spor yapmayan bireyler arasında dinlenmenin sağliklı olmada öncelikli olduğu, olumlu düşüncenin hastalıklarla savaşta önemli olduğu ve stresli yaşam koşulları olan insanların daha sık hastalıklara maruz kalabileceği düşüncesinin yaygın olduğu görülmüştür $(p<0,05)$.

Okuma alışkanlığı ile "inanç hastalıkla mücadele de önemlidir." ve "dinlenme sağlıklı olmada öncelikli koşullardandır." ifadeleri arasında anlamlı ilişkiler tespit edilmiştir $(\mathrm{p}<0,05)$. Okuma alışkanlığ 1 olanların inancın sağlıkla mücadelede önemli olduğu ve dinlenmenin sağlıklı olmada öncelikli koşullardan olduğu düşüncesinin daha yaygın olduğu görülmüştür.

Kent kültüründe yaşayan bireyler arasında stresli yaşam koşullarının insanları daha sık hasta edebileceği düşüncesinin daha yaygın olduğu tespit edilmiştir $(\mathrm{p}<0,05)$.

\section{Tartıșma}

Tinsel kelimesi, Türk Dil Kurumu sözlüğünde ruhi, manevi kelimeleriyle karşılık bulmaktadır. Tinsellik, bireyin kendisinin ve varoluşunun ötesindeki güçtür. Başka bir tanımda ise hem fiziksel boyutu kapsayan hem de onun ötesindeki kişisel farkındalıktır. Dolayısıyla, bireyin, yaşamın anlamını ve amacını yakaladığı yer onun tinsel alanıdır (Tuncay, 2007, s.10). Araştırmalarda, kişinin tinsel inançlarının sağlığı, uzun yaşamayı ve fiziksel hastalığın iyileşmesini pozitif olarak etkileyebildiği gösterilmiştir (Rippentrop, Altmaier, Chen, Found ve Keffala, 2005, s.311). 
Çalışmamızda katılımcıların çoğunluğu inancın sağlıkla mücadelede önemli olduğunu düşünmektedir. Ellison ve arkadaşları 2018 araştırmasında, inancın sağlık göstergeleri üzerinde olumlu etkisinin olduğunu bildirmiştir (Ellison ve Levin, 2018, s.449).

Çalışmamızda katılımcıların çoğunluğu dinlenmenin sağlıklı olmada etkili olduğunu bildirmişlerdir. Kurt ve arkadaşları 2010 araştırmalarında, iyi uyku ve dinlenmenin bireyde canlılık sağladığını, sinir sistemi ve metabolizma üzerinde olumlu etkileri olduğunu bildirmişlerdir (Kurt, Pekünlü, Çatıkkaş ve Atalağ, 2010, s.70).

Dinlenme belli bir aktivitenin kısıtlı olarak kesilmesi, kişinin kendini rahatlatma girişimi olarak tanımlanabilir. Dinlenme sürekli hareketsizliği ifade etmez (aktif dinlenme). Hastalık durumunda yeterli dinlenme çok önemlidir. Dinlenme kişilere güç, motivasyon, mental ve fiziksel sağlık, yaşam kalitesinde artış sağlar (Çakırcalı,1998).

Çalışmamızda bekar bireylerin arasında dinlenmenin sağlıklı olmada öncelikli koşul olduğu düşüncesinin daha fazla yaygin olduğu tespit edilmiştir. Algın ve arkadaşları 2016 çalışmalarında; uyku ve dinlenmenin insan sağlığının kaliteli sürdürülmesinde önemli olduğunu, zihinsel, fiziksel sağlı̆̆ımızı, yaşam fonksiyonlarımızı korumada yardımcı olduğunu bildirmişlerdir. Uykunun yenilenmeyi sağlama, enerjiyi koruma, yaşlanma sürecinde gecikme, immün sistemi koruma, vücut 1sısını koruma, korneayı koruma, nöral sistemi koruma sağladığını bildirilmiştir (Algın, Akdağ, Erdinç, 2016, s.29).

Çalışmamızda katılımcıların çoğunluğu olumlu düşüncelerin sağlıkta etkili olduğunu belirtmiştir. Bilge 2012 çalışmasında, olumlu düşünce ile yaşam kalitesi, sağlık arasında önemli ilişki olduğunu bildirmişdir (Bilge, 2012, s.129).

Çalışmamızda katılımcıların çoğunluğu stresli yaşam koşullarının hastalıklar üzerinde etkisinin olabileceği düşüncesindedirler. Erdoğan ve arkadaşları 2009, Baltaş ve ark. 1995, Bozkurt 2004 çalışmalarında, stresle sağlık arasında ilişki olduğunu bildirmişlerdir (Erdoğan, Ünsar ve Süt, 2009, s.447; Baltaş A.ve Baltaş Z., 1995; Bozkurt, 2004).

Üniversite mezunlarının diğer eğitim düzeyindekilere göre daha fazla oranda olumlu düşüncenin hastalıklarla mücadelede önemli olduğunu düşünceleri olduğu saptanmıştır. Duran ve arkadaşları 2017 üniversite öğrencilerinin olumsuz düşünme puanları yüksek olanların not 
ortalamasının düşük olduğunu bulmuştur. İlden ve arkadaşları 2002 olumsuz düşüncelerin bireylerde, kendine güveni düşürdüğünü, başarısızlığı önceden kabullenme durumlarının arttı̆̆ını, problemlerin çözümüne farklı yöntem düşünmelerine engel olduğunu ve sorunlarla baş etme yeteneklerinin azaldığını belirtmişlerdir. Çalışmamızda memurların tamamı olumlu düşüncenin hastalıklarla mücadelede bedene yardım edeceği görüşünde hem fikirdir. Çalışmalarda geliri olan bireylerin olumlu düşüncelerinin yüksek olduğu bildirilmiştir (Duran, Karadaş ve Kaynak, 2017, s.30; İlden, Günay ve Şener, 2002, s.100).

Çalışmamızda aile ile yaşayanların yalnız yaşayanlara göre stresli yaşam koşullarının hastalıklar üzerindeki etkisi olduğunu bildirme oranlarının yüksek olduğu belirlenmiştir. Literatürde evlilikte stres ve depresyon oranlarının ve bunlara bağlı hastalıkların önemli düzeyde yüksek olduğu, geliri yüksek ülkelerde 10 kadından birinde perinatal depresyon olduğu, gelişmekte olan ülkelerde 5 kadından 1'inde perinatal depresyon bulunduğu bildirilmektedir (Boran, 2017).

Çalışmamızda GDO'lu ürün kullanmayanların daha fazla oranda olumlu düşüncenin hastalıklarla savaşta bedene yardım edeceği inancı yaygındır. Literatürde dengeli beslenme, gelir düzeyi, olumlu düşünce ve sağlık arasında bağ olduğu, düşük ve orta gelirli ülkelerde kadınların yaklaşık \%20'sinin doğum sonrası ruh sağlığı problemleri yaşadıkları, bu oranın; yüksek gelirli ülkelerin yaklaşık iki katı olduğu belirtilmektedir (Boran, 2017).

Fizik aktivite ve egzersiz, tarih boyunca farklı uygarlıklar ve toplumlarda, yaşamın bütün dönemlerinde önemli bir yer tutmuştur. Egzersiz için genç-yaşlı ayırımı yoktur, her yaşta sağlığa yararlıdır. Bek 2008 çalışmasında düzenli fiziksel aktivite, çocukların ve gençlerin sağlıklı büyümesi ve gelişmesinde, karakter gelişiminde istenmeyen kötü alışkanlıklardan kurtulmada, sosyalleşmede, yetişkinlerin çeşitli kronik hastalıklardan korunmasında veya bu hastalıkların tedavisinde veya tedavinin desteklenmesinde, yaşlıların aktif bir yaşlılık dönemi geçirmelerinin sağlanmasında, zihinsel ve bedensel fonksiyonların korunmasında bir başka deyişle tüm hayat boyunca yaşam kalitesinin artırılmasında önemli farklar yaratabileceğine işaret etmiştir (Bek, 2008).

Çalışmamızda spor yapmayan bireyler arasında dinlenmenin sağlıklı olmada öncelikli olduğu, olumlu düşüncenin hastalıklarla savaşta önemli 
olduğu ve stresli yaşam koşullarının hastalıklara maruz kalmayı etkileyeceği düşüncelerinin yaygın olduğu görülmüştür. Başar ve Sarı 2018 düzenli fiziksel aktivite yapanların, yapmayanlara göre yüksek, mutluluk ve psikolojik iyi oluş puanlarının bulunduğunu belirlemişlerdir (Başar ve Sarı, 2018, s.25).

Okuma alışkanlığı olanların inancın sağlıkla mücadelede önemli olduğu ve dinlenmenin sağlıklı olmada öncelikli koşullardan olduğu düşüncesinin daha yaygın olduğu görülmüştür. Özdemir okuma alışkanlığının bireylerde serbest zaman etkinliğini değerlendirmesini, inançlarının farkına varmasını, bireyselliğini fark etmesini, öğrenmenin kolaylaşmasını, zenginleşmesini, toplumla bağlarını kuvvetlendirmesini, ilişkilerini güçlendirmesini, davranışlarını yönlendirmesini ve dünyadaki yerini anlamasını sağladığını belirtmiştir (Özdemir, 1983, s.1).

Çalışmamızda kendini kent kültüründe hissedenlerin kır kültüründekilere göre stresli yaşam koşullarının insanları daha sık hasta edebileceği düşüncesinin daha yaygın olduğu tespit edilmiştir. Kaya 2019 çalışmasında; kent memnuniyeti, yaşam doyumu ve stresle başa çıkma arasında anlamlı ilişki bulmuştur. İstanbul'un, gürültü kirliliği, ev kira fiyatlarının fazla olması, insan çokluğu, hava kirliliği, çarpık kentleşme açlarından memnun olunmayan kent olarak tanımlandığını belirtmiştir (Kaya, 2019, s.1).

Sağlıklı bireyler için olumlu düşünme, stresten uzak kalma, sağlıklı olma inancl, egzersiz yapma ne kadar önemliyse aynı şekilde bu düşünceler hasta bireyler içinde geçerlidir. Hastalığı kabullenme ve hekimine güvenme, verilen tedaviye uyum, iyileşeceğine inanma hastalığın atlatılmasında son derece önemlidir. Farmakolojide ilaç uyuncu adı verilen kavram tüm bu bileşenleri içinde barındırmaktadır. Tedavi uyumuna dair literatürde "compliance", "adherence" ve "concordance" gibi farklı kavramlar kullanılmaktadır. Türkçe literatür değerlendirildiğinde ise bu terimler arasında anlam farkı gözetilmeksizin tümünün uyum ve uyunç kelimeleriyle karşılandığı görülmektedir. Uyumun kısa ve kabul edilebilir tanımı; hastanın sağlığıyla ilgili önerileri kabul etmesidir. Aynı zamanda uyum sözcügü, terapötik ilişki kurarken hekimin rolüne ve hastanın katılımına önem yükler. Uyum tanımı, kontrollere katılım ve sağlıklı bir hayat modeline tutunmayı, aynı 
zamanda reçete edilen ilaçları uygun zamanda ve uygun dozlarda almayı da içine alır (Mehmet, Tamam, 2016, s.85).

Sağlık profesyoneli-hasta ilişkisi ne kadar güçlü olursa, hasta ilaç uyumu o denli güçlü olur. Bu durum zaten karmaşık olan ve direnç gelişme riski olan tedavilerde başarı oranını ciddi anlamda artırır (Çelen, 2013, s.3).

\section{Sonuç}

Tedavi uyumu hastalık seyrini, hastalığa bağlı morbiditeyi, hastanın sosyal, mesleki ve ailesel işlevselliğini etkilemektedir. Hastaların tedaviye genelde kısmen uyum gösterdiklerinin bilinmesi ve uyumu etkileyen faktörlerin belirlenmesi, çözüm önerileri sunulması hastaların tedaviye uyumunu arttıracak ve hastalığın sebep olduğu yıkımı, tedavi maliyetini, iş gücü kaybını en aza indirecektir.

Çalışmamızda sağlıklı yaşamak için olumlu düşünme, egzersiz yapma, stresten uzak kalma, hastalıklarla mücadelede inançlı olma düşüncelerinin katılımcılar tarafından önemsendiği belirlenmiştir. Sosyodemografik değişkenlerle olumlu düşünce, dinlenme, GDO lu ve organik besin tüketimi, stresli yaşama bakış arasında ilişki olduğu belirlenmiştir. Çalışma bulgularımızın planlanacak yeni araştırmalara, sağlık davranışı ile ilgili yeni eğitimlere yön gösterebileceğini söyleyebiliriz. 


\title{
EXTENDED ABSTRACT
}

\section{Individuals Opinion on Healty Living Subject}

\author{
Nuriye Değirmen- Filiz Özyiğit \\ Kütahya Sağlık Bilimleri University
}

Inroduction: Being healthy is defined as the physical, mental and social well-being of individuals. Lifestyle has a significant impact on health. Significant reductions in morbidity and mortality can be achieved with healthy lifestyle changes. Research on the subject is needed. Aim: Aim of this study is evaluation of health behaviours and opinions of individuals. Descriptive, 330 individuals in a Family Health Center, made between October-December 2019 of voluntary by face to face. The questionnaire form was created by the researchers based on the literature. In the first part of the questionnaire, there are questions to determine the demographic characteristics, family life, health status, diet and economic conditions of the individuals. In the second part, there were questions to determine the opinions of individuals about being healthy. Ethics committee approval was obtained for the research. Ethics committee approval; It was obtained from Kütahya Health Sciences University with the letter dated 18.12.2018 and numbered 4135. The sample calculation method was used in the study. Dependent variables; it is the sociodemographic data of the participants. Independent variables; they are the answers given by the participants to the healthy life questions. Descriptive statistics were used to determine the socio-demographic characteristics of individuals and their thoughts on being healthy. Chi-square analysis was used to determine the significant relationships between the sociodemographic characteristics of the participants and their thoughts about healthy. Limitations; the findings of the study are limited to the opinions of the participants who received service from a family health center at the relevant date. Findings: $71.7 \%$ of the participants are woman, half are married and university graduates, $81 \%$ of them live in a elementary family, there are households where, on average, 4 people with 2 children live in the same house. $71.8 \%$ of them have a mid economic situation, $88.9 \%$ of them have a social security, $67.7 \%$ feel themselves in urban 
culture, $20.1 \%$ smoke and use alcohol, $65.8 \%$ of them stated that they consume organic food, $57.1 \%$ of them use GMO products, $62.8 \%$ of the don't exercise. The majority of the participants think that belief is important in the fight against health. The idea that rest is important for being healthy was adopted by the participants. The opinion of the participants that positive thoughts can have an effect on diseases is dominant. Marital status and "rest is one of the primary conditions for being healthy." and "people with stressful living conditions get sick more often and their illness lasts longer." a statistically significant relationship was found between the expressions $(\mathrm{p}<0.05)$. It is common for single individuals to think that resting is important for being healty $(\mathrm{p}<0.05)$. A significant relationship was also found between the level of education and the thought that positive thinking can help the body in the fight against diseases $(p<0.05)$. Among university graduates, $98 \%$ stated that positive thinking is important in the fight against diseases. A significant relationship was also found between the idea that positive thinking is important in the fight against diseases and the profession $(\mathrm{p}<0.05)$. Officials, workers, retirees all agree that positive thinking will help the body fight disease. A statistically significant relationship was found between the effects of stressful living conditions on diseases and family life $(p<0.05)$. It is common for those who do not use GMO products to think that more positive thoughts will be effective in fighting diseases $(p<0.05)$.The thoughts were common on people who don't exercise; effect on rest on health, the effect on positive thinking on diseases and the effect on stressful life on diseases $(p<0,05)$. With the habit of reading, "belief is also important in fighting the disease." and "rest is one of the primary conditions for being healthy." Significant relationships were found between the expressions $(\mathrm{p}<0.05)$. It has been observed that those who have the habit of reading believe that belief is important in the fight against health and that rest is a priority condition for being healthy. It has been determined that the idea that stressful living conditions can make people sick more frequently among individuals living in urban culture $(p<0.05)$. Most of them care about the using prescription drugs. Result: The majority of the participants in our study think that belief is important in the fight against health. The literature has reported that belief has a positive effect on health indicators. It found important that positive 
thinking, exercising, avoiding stress in being healty by participants, relationship between socio-demographic variables and positive thinking, resting GMO, organic food consumption and stressful life. As important as positive thinking, staying away from stress, belief in being healthy and exercising are important for healthy individuals, these thoughts are also valid for sick individuals. Accepting the disease and trusting the physician, complying with the treatment given, believing that it will get better are extremely important in overcoming the disease.

\section{Kaynakça / References}

Algın, D.İ., Akdağ, G., ve Erdinç, O.O. (2016). Kaliteli uyku ve uyku bozuklukları. Osmangazi Tip Dergisi, 1, 29-34. DOI: 10.20515/otd.40263.

Aydın, Ş. ve Örnek A.Ş. (2008). Kriz ve stres yönetimi. Ankara: Detay Yayıncilik.

Balcıoğlu, İ. (2005). Medikal açıdan stres ve çareleri. İstanbul: İ.Ü. Cerrahpaşa Tıp Fakültesi Sürekli Tıp Eğitimi Etkinlikleri. Sempozyum Dizisi.

Baltaş, A. ve Baltaş, Z. (1995). Stres ve başa çıkma yolları. İstanbul: Remzi Kitabevi.

Başar, S. ve Sarı, İ. (2018). Düzenli egzersizin depresyon, mutluluk ve psikolojik iyi oluş üzerine etkisi. İnönü Üniversitesi, Beden Eğitimi ve Spor Bilimleri Dergisi (IÜBESBD), 5(3), 25-34.

Bek, N. (2008). Fiziksel aktivite ve sağlığımız. Ankara: Sağlık Bakanlığı Yayını. Bilge, A. (2012). Yaşama dair olumlu düşünce. Ege Üniversitesi Hemşirelik Fakültesi Dergisi, 28(3), 129-135.

Dünya Sağlık Örgütü. (2015). Thinking healthy: A manuel for psychological management of perinatal depression. P. Boran (Çev.) Sağlıklı Düşünmek. İstanbul: Marmara Üniversitesi Yayınları.

Bozkurt, N. (2004). Stres, "Öğretmen Stresi ve Stresle Başaçıkma Yöntemleri". Ankara: Kişisel Gelişimde Çağdaş Yönelimler Sempozyumu.

Büyüköztürk, Ş. (2018). Sosyal bilimler için veri analizi el kitabı. Ankara: Pegem Atıf İndeksi.

Çakırcalı, E. (1998). Hemşirelikte temel ilke ve uygulamalar. İzmir: Ege Üniversitesi Basımevi. 
Çelen, M.K. (2013). Kronik hepatit B'li hastada hekim-hasta uyumsuzluğunun ilaç direncine olan etkisi. Turkiye Klinikleri J Inf Dis-Special Topics, 6(1), 90-3.

Duran, S., Karadaş, A. ve Kaynak, S. (2017). Hemşirelik öğrencilerinin olumsuz otomatik düşünceleri ve akademik başarıları arasındaki ilişki. Kocaeli Medical J, 6(2), 30-37.

Ellison, C.G., Levin, J.S. (2018). Din-sağlık ilişkisi: Kanıt, teori ve geleceğe yönelik öneriler. F. B. Arvas (Çev.). Din Bilimleri Akademik Araştırma Dergisi, 18(2), 449-478.

Erdoğan, T., Ünsar, A.S. ve Süt, N. (2009). Stresin çalışanlar üzerindeki etkileri: Bir araştırma. Süleyman Demirel Üniversitesi İktisadi ve İdari Bilimler Fakültesi Dergisi,14(2), 447-461.

Ertüzün, E. ve Karaküçük, S. (2014). Sağlık inanç modeli perpektifinde sportif rekreasyon aktivitelerine bakış. Gazi Beden Eğitimi ve Spor Bilimleri Dergisi, 19(1-4), 1-9.

Ferguson, K. J. (1998). Wallace RB. public healthe preventive medicine. Stamford: Appleton\& Lange.

İlden, K.A., Günay, K.B. ve Şener, Ş. (2002). İlköğretim öğrencilerinde sınav kaygısı ve akademik başarı. Çocuk ve Gençlik Ruh Sağ̆lğ̆ Dergisi, 9(2), 100-105.

Kavas, A. (2003). Sağlıklı yaşam için doğru beslenme. İstanbul: Literatür Yayincilik.

Kaya, F.Ş. (2019). Kent yaşamı memnuniyeti, stresle başa çıkma ve yaşam doyumu ilişkisi: İstanbul örneği. Stratejik ve Sosyal Araştırmalar Dergisi, 3(2), 1-10. DOI: 10.30692/sisad.584622.

Kurt, C., Pekünlü, E., Çatıkkaş, F. ve Atalağ, O. (2010). Tam ve kısmi uyku yoksunluğunda performans. BESBD, 5(1), 70-76.

Mehmet, E.D. ve Tamam, L. (2016). Treatment adherence in psychiatric disorders. Psikiyatride Güncel Yaklaşımlar, 8(1), 85-93.

Özdemir, E. (1983). Okuma sanatı: Nasıl okumal, neler okumalı? İstanbul: İnkılâp Yayınevi.

Peker, A.T. ve Zengin, S. (2019). Sağlık hizmetleri meslek yüksekokulu öğrencilerinin spor sağlık inanç düzeylerinin değerlendirilmesi. Ekev Akademi Dergisi, 77, 45-56. 
Rippentrop, A.E., Altmaier, E.M., Chen, J.J., Found, E.M. ve Keffala, V.J. (2005). The relationship between religion/spirituality and physical health, mental health, and pain in a chronic pain population. Pain,116, 311-321. DOI: 10.1016/j.pain.2005.05.008.

Şimşekoğlu, N. ve Mayda, A.S. (2016). Bir üniversite hastanesinde görevli hemşirelerin sağlıklı yaşam biçimi davranışları ve sağlık kaygısı düzeyleri. Düzce Üniversitesi Sağlık Bilimleri Enstitüsü Dergisi, 6(1), 19-29.

Soylu, M. (2006). Sağllklı beslenme-sağllklı süt. I. Ulusal Sağlı̆̆ı Geliştirme ve Sağllk Eğitimi Kongresi Özet Kitabı. Muğla: 20 Ocak .2010 tarihinde http://www.wacc.mu.edu.tr/ozet\%20kitabi.pdf adresinden erişildi.

Tuncay, T. (2007). Spirituality in coping with HIV/AIDS., HIV \& AIDS Review, 8(3), 10-16. DOI:10.1016/S1730-1270(10)60073-2.

Ünsal, A. (2017). Hemşireliğin dört temel kavramı: İnsan, çevre, sağlık \& hastalık, hemşirelik. Ahi Evran Üniversitesi Sağllk Bilimleri Dergisi, 1(1), 11-28.

\section{Kaynakça Bilgisi / Citation Information}

Değirmen, N. ve Özyiğit, F. (2021). Bireylerin sağlıklı yaşam konusuna ilişkin görüşleri. OPUS- Uluslararası Toplum Araştırmaları Dergisi, 18(42), 5378-5397. DOI: 10.26466/opus.918671. 